\title{
Introduction: Security, Exclusion, and Social Justice
}

\author{
WILLEM DE LINT ${ }^{1}$ \\ Department of Sociology, Anthropology, and Criminology, University of Windsor
}

Two concepts animate this special issue of Studies in Social Justice: exclusion and security. Exclusion and exclusivity are often understood as inimical to social justice in-so-far as one broad category of wrongs results in the denial of access to goods, services, and rights to some people. In a very popular book, Jock Young (1999) captures this understanding and makes the case that we are becoming the "exclusive society." He argues that a welfarist model of social protection that absorbed and accommodated diverse populations is being displaced with a neoliberal one that limits the distributive function of government by reference to a (false) claim to market efficiencies. In the "exclusive society," identities and lifestyles are marginalized, scapegoated, fragmented, and stigmatized.

Security is, perhaps, the first claim on government, and it is a revivified concept in a vast number of disciplinary traditions because it is connotative and resonant: it connects the personal and political, the quotidian and existential, hopes and fears; it is also a bridge concept between the needs of individuals or subjects and the organization of social and political bodies. In much scholarly literature and in a growing body of official policy, the call for a more inclusive concept of security is made so that security is not primarily or ultimately a commodity of geopolitics, but is inclusive of human rights and, indeed, the necessities of life (food, water, shelter) for those who are most disadvantaged. Consequently, it is suggested, security must encompass those who are commonly the object rather than the subject of security talk. Indeed, the relation between inclusion and security is tantalizing for those concerned with social justice because it is suggestive of community, oneness, solidarity, peace. Who but an elitist would champion exclusion and exclusivity?

The trajectory of modernism and liberal politics is not merely an iterative or reflexive process of absorption, it is also a projection of justified exclusions. The idea that exclusivity and injustice are interchangeable or mutually reinforcing has an immediate but temporary appeal. To provide a concrete illustration, advocates of social justice are correct to assert that the principles at back of a rule of law that empower institutions such as the International Criminal Court or organizations like 
Human Rights Watch are meaningless if they cannot be employed to subordinate powerful outlaws. It is at this point that International Relations realism and idealism meet head-on because it is here that champions of justice seek the coercive powers of enforcement that authorize banishments, punishments, and deprivations, that is to say, where the application of a remedy against a transgression is maintained by a legitimate coercive power yet the power to resist that coercive capacity is not reduced. At the same time, many scholars and practitioners have been searching for and experimenting on the means to insert at the quotidian register a kind of empowerment that does not imply reactionary populism or mob tyranny. How to launch justice and rights (how even to conceive that there is something of value in these terms) without a "grand narrative" is a question that animates much recent debate (O’Malley, 2008).

In Diagram 1 presented below I have depicted security and justice across two dimensions: the exclusivity of subjects (elite versus common) and the exclusivity of jurisdictional resources (global versus local). As I have noted, critical thinking about the relation between justice and security often begins with the assumption that their confluence is least likely in the upper median. The traditional critical view is launched from subjectivities and jurisdictions (not states or regions but villages or disenfranchised peoples) that appear to seek a redistribution of resources and a reintegration of subjects. This is a scalar and vector oppositional to the (realist) view that launches security as geopolitical and makes justice derivative- - the legitimation/ delegitimation of elite global economic rapprochements.

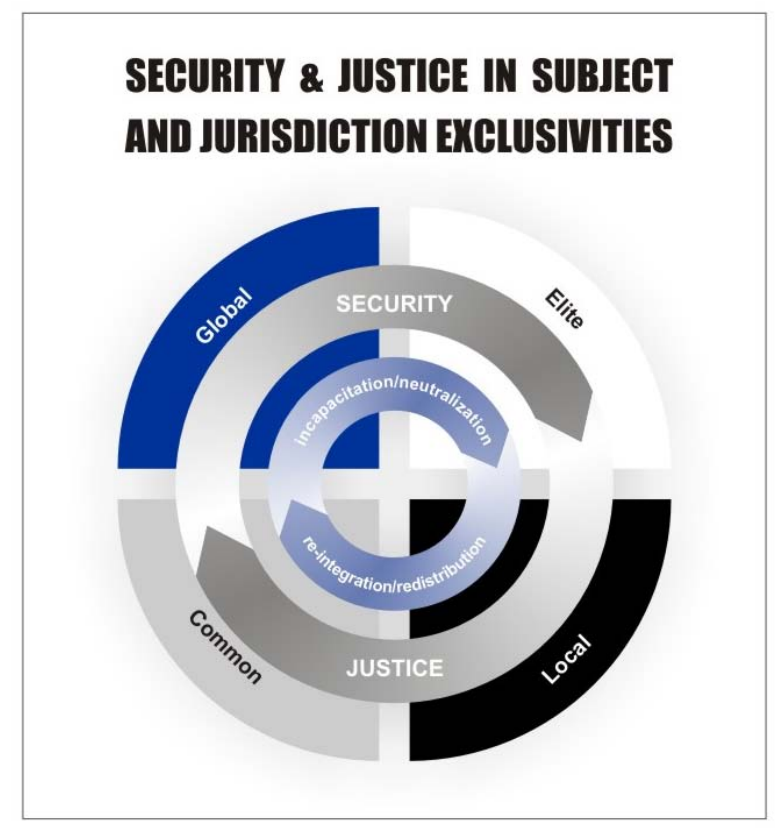

Diagram 1. Security and Justice across Subject and Jurisdiction Exclusions 
Advocates of "justice in security" who value a republican ideal may favour growing local or "community peaces" by building capacity (and interaction) at the scalar of a village. ${ }^{2}$ Those who place greater value on universality may instead insist on "security in justice" or standards that apply with equal weight and result no matter the local interaction dynamics. The presumption is generally that, where the emphasis is on the local and common, subjects are more likely to be capacitated for reintegrative justice and jurisdictional resources are more likely to be redistributive, ${ }^{3}$ but as has been noted (e.g., Zedner, 2009), this is not necessarily borne out in practice. Elites can be local as well as global and the parochialism of everyday security and the local administration of justice is often moderated by values or meanings that are exogenous or even transcendent.

In many conceptual puzzles it is the missing piece that often holds the key. Here, this is at the juncture where the relationship between distributive and penal justice comes back into play. If justice refers to a process to distribute valued resources along the axes of social norms, and security is the precondition of this process, to be "just and secure" is an ideal whose expression will regularly depend upon the review of exceptions and exclusions by intrinsic and extrinsic forces. Subjects may be reintegrated (restorative justice) or neutralized (incapacitated, punished, deprived), and jurisdictional resources may be offered to lower jurisdictional denominations or withheld (as a function of legitimating an extant security order).

Perhaps this is resolved, as per Derrida (2001), where political action is taken between "a moment of universality" and "pragmatic demands" of politics in a specific context. Following a thread also explored by Arendt (1967) and Mouffe (2005), it is not that the unforgivable must always be forgiven or that those who most threaten us must be embraced, but that there is sufficient political space that this remains a possibility. Contrary to Young, it is not with a nostalgic turn to modernism, but with an agonistic view of politics (as always open to revision and provocation) that the problem of exclusive security may most fruitfully be attacked. It is in this spirit that we undertook to canvass scholarly views on the problem. These views range from those who offer critique or interrogation of current iterations of the relation between these concepts to those who make a stab at the hard work of proposing the contours of that political space.

The first paper is David Mutimer's critique of critical security studies. Mutimer begins by noting how security in traditional International Relations studies has derived its subject-matter through discursive elisions, including most notably the production of an excluded (non-citizen, non-state) other. However, far from correcting the exclusionary character of security thinking, critical security studies produce their own set of subjects that are not granted status. Here, one of the most peculiar exclusions reviewed is that of the CASE (Critical Approaches to Security in Europe) Collective, which while encompassing a wide range of critical security scholars is also confounded by its self-imposed European identity and its exclusion of postmodernists and feminists. As Mutimer summarizes, this overt attempt at an inclusive network-building exercise has received the sharpest criticism from those whose voices appear not to be invited into the Collective's ambit. However, in speaking on security as on many issues of social policy, it is inevitable that there will be some that we will include and speak in favour of and some we will place beyond a margin and ignore or speak ill of. Security, of course, is a way of talking about and justifying the inevitably unequal distribution of precious resources. 
In his critique of security, Neocleous suggests that the logic of security, rather than liberty, is foundational in liberal democratic societies. Within this logic of security, liberal democracies replicate fascist and authoritarian political dimensions in the use of values and identity to frame the security problem. When security comes to be understood as a threat to national identity or a "way of life" generally, distinctions between liberal and authoritarian politics, as well as distinctions between internal and external threats, are obliterated-and internal enemies are seen as integral to external enemies and vice versa. National security, loyalty, and political unity are values mobilized as much by authoritarian as liberal regimes, and comprise the authoritarian dimensions at the foundation of liberalism.

In their examination of Canada-US border security, O’Connor and de Lint argue that frontier government is an expansionist move that links an invigorated sovereign capacity with strategies of control, surveillance, and risk management to create a new governance assemblage. Frontier expansion enlists various agents and agencies, public and private, as well as numerous "petty sovereigns" seeking to apply a new "governance normal" in novel sites, marking outposts farther from the traditional land border. The new governance normal makes use of intelligence and intelligence gathering strategies to secure the expanded borderlands, where new "information tolls" make arriving at the border unannounced a thing of the past and where private partners are enlisted to do more of the governing in a frontier that reaches deep into the global supply chain. Ostensibly for the immunization against risks or harms, frontier government also serves to augment sovereign capacity. With new exclusive knowledge resources and technological means at its disposal, as well as an expanded registry of known and unknown risks to secure against, this invigorated sovereignty is mobilized by quotidian decision-makers to roll back laws/rights and roll out "counter-law" in the normalization of exception or the diffusion of border agency everywhere.

Muller argues that the events of 9/11 have resulted in a virulent spread of exclusionary practices at the border in terms of a risk management logic and biometric technologies focused on identity management and therefore on exclusion. This re-articulation of security, danger and identity, has lead to a proliferation of border practices, both at and beyond the physical land border. The borderland is now governed through risk, where risk management and the securitization of identity visà-vis biometric technologies are held up as the answer to the dilemmas of border security. Risk management, in its four-fold articulation of responses (acceptance, mitigation, avoidance, or transfer of risk), discloses a tension and reveals an ambiguity among the many authorities responsible for securing the border. This ambiguous authority structure results in potentially dire consequences. Echoing Donais' concern about "who" these security schemes actually serve, who enjoys or is denied the ability to "speak" and to "do" security, Muller argues that the current border security regime is aligned with a limited and narrow set of political objectives associated with US homeland security. The limited goals of the current border security regime excludes various long standing collaborative and cooperative cultural, political, and market voices that (used to) inform practices in the borderland.

Canada is known as a longstanding advocate of widening understanding of "security" from the realism of international relations that has traditionally structured 
much state-to-state interaction. However, as shown by a number of authors in this issue (Essex, Hills, Neocleous, Mutimer) there are many reasons to find that the concept of security remains a blunt instrument even where it is widened to include human needs such as food and medicine. As Essex demonstrates, food-for-work (FFW) programs are a disciplinary mechanism that links hunger to poverty and food insecurity to geopolitical insecurity. Access to U.S. food aid, for example, is dependent on compliance with donor interests for showing a return on investment, particularly as an entry point for advancing "geopolitical and geoeconomic objectives in recipient countries." Such programs can "crowd out” and displace local political and economic practices that contribute to a dependent or client state status at the same time that they draw on existing local systems for their administration, exacerbating faulty or corrupt systems and practices. It is particularly the suppression of local political demands that Essex explores in his case study of the Jakarta FFW program.

In everyday usage, the term "security" connotes a common and connective function and this is why it is so attractive. In this respect, it performs much in the way the term "community" to win converts to policies or initiatives (for example, "community policing"). Such usage, however, is open to the exclusions of subjects and identities, and much as community policing is morphologically prone to militaristic properties, forces of elitism and elite or special forces also share common terrain in dual policing export experiments. In her study of U.S. led efforts to set down "security" in Baghdad and Basra in post-invasion Iraq, Hills argues that the experience of security is often neither common nor connecting. On the contrary, it is "rarely for all." For whom and for what, of course, are the key questions when a post-Wilsonian military adventurism stands tall in the shadows and efforts to impose an internal order are by force of an occupying army (which understands its own security as paramount). When Paul Bremmer, as head of the CPA, dissolved the Ba'ath Party (and with it institutional structure of Iraqi policing) in order to create a new Iraqi Police Service mandated to assist coalition forces in addition to crime control and order maintenance, the "for whom" question of Iraqi security could not have been made more jarringly clear: security is produced as a "selective project" and understood and expressed by personalities according to strategic or political contingencies. Offering her examination partly as a corrective to its adaptation by elite sensibilities, the meaning of security in a post-conflict city refers to "something more physical, territorial, and exclusionary." It does not, and given how easily it is sutured to the agendas of those imposing from without perhaps should not, extend too far from the question of who is "forcibly displaced, raped, robbed, kidnapped, mutilated, tortured, or killed."

The expansionist moves that promote security through the spread of national (identity) values and the concern about security as an export commodity are also reflected in Donais argument that security sector reform (SSR) in so-called "transition" countries is an externally-driven social engineering project in which "donor" countries aim to make over the security sector in the image of Western priorities. SSR efforts typically require the security sector to be reformed along the axis of Western values and institutions, reflecting the belief that these values and institutions are universally valid, the only legitimate basis for good security governance, and are necessary elements in the "democratic transition" in countries emerging from war and/or authoritarianism. In this case, "local ownership" of the 
SSR process is reduced to the responsibility to adopt Western-style security norms, values, and institutional frameworks (often linked to donor country security pursuits such as the war on terror) and local ownership becomes an end rather than a means of security sector reform. Without substantive local ownership, however, security sector reforms tend to be thinly institutionalized and norms weakly internalized. Local ownership can also be used by local governments as a means of suppressing dissent or undermining political opponents. These aspects of SSR reveal basic tensions at the heart of such strategies. The way to address the lived insecurities of people in transition countries is to consider SSR as a negotiated partnership between donors and local elites, including discussions about whether and how international security sector norms can be reconciled, not only with local traditions, practices, and values, but also with the more parochial interests of local elites.

This summary of the contributions to this issue invites a closing observation. The distribution of access to valued resources such as security (including debate about its representation or delimitation) is indeed a measure of political space as suggested by Derrida. That space is almost limitless where it is conceived between the "moment of universality" and "pragmatic demands." One may read each of the papers in this issue with an eye to this: at stake is not only the occupation of the space between these terms, but also the position at which the decision is made: who gets to determine, when, and under what conditions that something should register as pragmatic or universal? In this way, the comment by Derrida also returns us to our point of departure. Security is so important a term because it is often the bluntest weapon, uttered to cut off debate. Even when it is reloaded to encompass universality (as with "human security" or "green security"), the process of division begins anew, as elites redefine both the universal and pragmatic to maintain the selective distribution of valued resources. This is why security is so pivotal: long perceived as antecedent to law, the space of the political, and the distributive work of government (as Bentham pointed out), it holds equal promise as an instrument of retrenchment and renewal.

\section{Notes}

${ }^{1}$ Willem de Lint would like to thank the Social Sciences and Humanities Research Council for a grant award under its Aid to Research Workshops program that contributed funds to this issue of Studies in Social Justice and Tanya Basok and the Centre for Studies in Social Justice for generous contributions to the grant proposal. Thanks also to Daniel O'Connor for helpful comments on this piece.

2 Taking food security as an example, in line with the work of Essex in this volume, Vandana Shiva has written how the so-called Green Revolution has devastated India's capacity as a food supplier to its own people because it supports the displacement of long-standing traditional farming methods that rely on plurality with a policy that serves elite global agribusiness (transnational) through monoculture. If the value here is access to food by local and common folk, then the displacement of global elites with common local production is the obvious solution, producing greater justice and security.

3 However, the means and ends of justice and security appear to be at loggerheads even within local spaces. As noted by Brodeur and Shearing (2005, p. 382), the administration of the court system often resides with departments of justice whereas policing agencies often fall under departments of (homeland) security or safety. This means that policing agencies are associated with security provision and the courts with the pursuit of justice. Citing polls that 
find that the Canadian public blame the courts more than the police for a lack of public safety, Brodeur and Shearing argue that security and justice are "more intertwined at the grass-roots level [of common perception] than is usually recognized.” (385)

\section{References}

Arendt, H. (1967). The origins of totalitarianism. London: George Allen and Unwin.

Brodeur, J-P. and Shearing, C. (2005). Configuring justice and security. European Journal of Criminology, 2(4), 379-406.

Derrida, J. (2001). Cosmopolitanism and forgiveness. London: Routledge.

Mouffe, C. (2004). The political. London: Verso.

O’Malley, P. (2008). Experiments in risk and criminal justice. Theoretical Criminology, 12(4), 451-469.

Young, J. (1999). The exclusive society. London: Sage.

Zedner, L. (2009). Security. London: Routledge. 